Original research article

\title{
One-way street? Spatiality of communities in low carbon transitions, in Scotland
}

\author{
G. Taylor Aiken \\ L'Institut de Géographie et Aménagement du Territoire, Université du Luxembourg, Luxembourg
}

\section{A R T I C L E I N F O}

\section{Keywords:}

Low carbon transitions

Community

Transition towns

Sociospatial theory

Lefebvre

Spatial turn

\begin{abstract}
A B S T R A C T
Community low carbon transitions - studies of the ways in which community is used to pursue environmental aims and objectives - are closely linked to arrangements of energy production and use. Community is used as a way to pursue particular energy agendas. Yet, as is often pointed out, the trajectory of transitions imagined, the ambitiousness of the envisioned transformation, and especially the implied community invoked within this, all remain gloriously inconsistent. Within community transitions attention increasingly focuses on the tensions emerging or smoothed over as competing agendas are brought together through capacious words and concepts: for example between so-called top-down government deployed community, and so-called bottom-up emergent community action. This paper offers one way to explain and explore these tensions, where they come from and, thus, help in understanding ways in which they may be overcome. Using the case study of an attempt to target one 'street community's' environmental footprint in Scotland, the paper argues for taking an explicitly geographical and spatial lens to analyse these processes. The paper uses three forms of space-perceived space, conceived space, and lived space-to outline how three distinct but overlapping communities were spatialised. The contention of the paper is that tensions in community transitions often result from different spatial imaginaries, informing one's approach to, and 'common sense' understanding of, community. In reflecting on the spatial implications different forms of community produce (and are in turn produced by), the article argues for greater appreciation of the imbrication of space, community, and energy as mutually co-constitutive.
\end{abstract}

\section{Introduction}

In the pursuit of energy transitions, community is increasingly discussed as means to help deliver low carbon ambitions. Whether this community is understood as a 'grassroots initiative' [1], 'grassroots innovation' [2-4], 'sustainability niche' [5], 'bottom-up' actor ([6], pp. 41-48; [7]), or simply a wider context in receipt of 'community benefits' $[8,9]$, community appears as an enabler of energy transitions. However, the picture is not only rosy. As often as community is suggested as being capable of enabling shifts in energy production and consumption, increasingly evidence is emerging that tensions exist within community transitions. These tensions include: a disconnect between community policy and community action in this area [10-13]; community adopted by states as a 'policy object' used to enroll citizens for their (energy) agendas [14], within the diverse, multiple and complex ways that community forms part of governing climate 'beyond the state' $[15,16]$; that place attachment can serve as a motivator and barrier for engaging in community renewable energy projects [17]; the multiple roles of justice [18-21] and cultural drivers within community energy [22]; the ways these initiatives are measured and evaluated causing frustrations for those involved [23,24]; the unevenness and difference in the communities enacting energy transitions, meaning some are far more trusted than others [25]; and what 'community' itself even means whenever applied in this area [26-30]. These aspects regularly accompany each other too. Karvonen [31] argues that community is simultaneously: the mesoscale of low carbon politics, an extension of existing government, identity politics, a knowledge network, and a manifestation of moral responsibility. Multiplicity of meaning and tensions do not have to be negative-'tensions can be both an opportunity and a threat to the often precarious existence of [a community] initiative' conclude Fischer et al. [32]—but they do call for further investigation.

This article argues that one way to understand the complexities of how community is used to meet low carbon objectives is to take an explicitly geographical approach. It argues that the ways community is spatialised is a fundamental component to these tensions. To do so, it takes evidence from one bespoke project where community was specifically called on to help reconfigure the energy relationships in one street: primarily in terms of energy consumption but also with a view to developing energy production. The article makes this case by, next,

E-mail address: gerald.aiken@uni.lu. 
offering an overview of community transitions. This section pays particular attention to a prominent example of this field-the Transition movement. ${ }^{1}$ An important distinction in what follows is between Transition and transition: Transition is a branded initiative, where groups follow Transition books, connect to the wider movement and have formal accreditation. Yet they also wish to transition as a (nonproper) noun, in this case towards a low carbon society. Given this, the article provides a brief, but in depth, overview of how space is variously perceived, conceived and lived, after Lefebvre. Section four then folds this spatial theory back into the field of community transitions. Following this, a methods section, followed by a more detailed case description, outlines the empirical example used here. Particular attention is given to how this project spatialised community. Immediately following, the conclusion returns to spatial theory, setting it alongside the empirical case study, and outlining what taking a spatial approach to community transitions has to offer.

\section{The inconsistent community of community transitions}

Community is nearly impossible in a highly monetized society like our own. That is because community is woven from gifts, which is ultimately why poor people often have stronger communities than rich people. If you are financially independent, then you really don't depend on your neighbors-or indeed on any specific person-for anything. You can just pay someone to do it, or pay someone else to do it

\section{‘quote of the month' for January 2012 [89]}

The Transition movement emerged from Totnes in Devon in 2005 $[33,34]$. Their oft-quoted rallying cry asserts: 'If we wait for governments, it'll be too little, too late. If we act as individuals, it'll be too little. But if we act as communities, it might be just enough, just in time' [35]. Commentators have variously interpreted Transition as a 'grassroots technological niche' [36], a practical working out of Deleuzean inspired politics [37], a permaculture-based social movement [38] or ethical place making [39]. Alternative readings emphasise Transition's focus on acceptability and accessibility over transformative political action $[40,41]$. What is constant though is identifying the central importance of community. Wilson sees Transition as 'the most prominent example of relocalized community' ([42], p. 68) in the quest for community resilience. Seyfang and Haxeltine stress the importance of Transition's 'community engagement processes and initiatives' ([3], p. 3). Kendrick imagines Transition fostering 'a community-based life, where the things that we need are produced largely through balancing the capacity of the local land to provide for the needs of the people who life on it' ([43], p. n.p). These are accurate: community is Transition's raison d'être.

The initiatives are 'community-led', firmly rooted in the 'local community', and their eventual goal is a 'resilient relocalised community'. Transition's specific mobilisation of community - seen in the above quote of the month-is also laden with disdain for aspects of 'Modern' life: mobility, affluence, individualism, and consumption. These all indicate a lack of community. This is a key insight from which to begin an analysis of Transition's community values. Community is seen as the antithesis of financial independence. Within this quote is the key assumption of what being community contains: not being an individual, involving greater association with and reliance on those who live nearby. The community here, acting as a cure for Modern ills, is a term synonymous with neighbourliness, locality and place. As Painter argues, 'in everyday usage these two notions [community and neighbourhood] are frequently conflated' ([44], p. 524). One could also add small-scale to this bundle of elisions. Transition's 'community' can—on

\footnotetext{
${ }^{1}$ The Transition movement are represented by Transition Network, distinct from wider transitioning projects: https://transitionnetwork.org.
}

the surface-be seen as a proxy for a (local-)community of place.

But Transition's community goes beyond this surface, topographical and reified understanding shared with the governmental deployment of community. Transition's reified veneer of (local-)community of place emerges from their internal heritage, alongside external context. Key Transition texts include Schumacher's Small is Beautiful ([45] [1973]) and writings on permaculture $[46,47]$. Another source of this call to the local community—that community implies a silent prefix, local—was a suspicion of larger scale ways of organising society. It partly results from the perceived failure of centrally planned economies and neoliberalism, and likely part of a belief in the more anarchic potential of small-scale, micro, and self-organising as a political vision. Thus Transition have spun-off many initiatives such as local currencies [48], local food networks [49], and renewable energy schemes [3]. These are based upon this permaculture vision of community-small-scale, local and modular [38]. Yet crucially Transition's community also invokes belonging and practical action. Transition believes that to be human is to belong to a community, as plants and animals belong to an ecosystem community. Community here is 'natural' and can be understood rationally and objectively: for instance, Dunbar's Number is used outline the optimum size of a community, around 150 people. Yet this permaculture community also assumes that community has a purposive agency: ecosystems 'naturally' gravitate towards succession; human communities likewise purposively seek to answer their 'fundamental human needs' $[50,51]$. Transition's community thus bridges the strategic deployment of community-with its surface elisions with local and neighbourhood-and also the emergent, practical being in and belonging to community. Transition's permaculture heritage attracts volunteers to a lived community; Transition's adaptive use of community as small-scale, and place-based allows the snug fit with their applications for community-funding streams. Of course, in each case only the word 'community' is vocalised, written or mentioned.

The question emerging here is how far Transition reflects the wider use of community, in that it covers multiple meanings? Throughout its long history community has been used to underpin various ideologies, ways of idealising and organising society, and normative perceptions of what constitutes the 'good life' [52,53]. Only within Carbon governance, community's variety extends to: 'an actor, a scale of activity, a spatial setting, a form of network and a type of process' ([54], p. 777). As Massey has argued, 'relations of dominance may be maintained precisely through the instabilities of meanings' ([55], p. 175). Like many community movements have previously, Transition both use community to cover multiple meanings, and commonly elide it with local, place, and small scale. Its polysemy is used deliberately to capture multiple meanings. The word community is both a stumbling block and enabler of action and building coalitions. At times it refers to experiential aspects: involvement, belonging, practical action, a 'natural' human condition of togetherness. At others it can denote the strategic: a more objective neighbourhood-level understanding of a community that can be rationally know and predicted.

Despite community's proliferation as a site, actor, and means to enact energy transition, we can still be none the wiser as to what this 'community' actually is, or does-other than some vague notion of what community transition is not: not individual-focused, not state-driven, not business-led. The argument in this paper is that taking a geographical approach to community transitions means being alive to the various way(s) in which this community is spatialized. To do that the next section offers a concise outline of some canonical theorizing of space, based on the work of Henri Lefebvre.

\section{Towards a geography of community transitions}

Space is central to geography and perhaps the only concept capable of unifying the discipline. Though not easy to define, space is used by geographers in a diffuse and inconsistent way. In this way, this article cannot speak for all uses of space, other than to say that space is 
centrally important. In terms of the special edition here, taking account of the 'geographies of energy production and use' must include an examination of space. Lefebvre, a canonical theoriser of space within geography, argued that space required more specificity, however did not offer a fixed definition of the term [56,57]. This argument has some antecedents. More widely, there rise and rise of understanding energy transitions geographically [58] and community within that [59,60]. More specifically, Lefebvre is called on by some, (including [61-63] as being particularly useful in outlining how 'the production of space' extends and deepens energy geography. This article then is part of the spatial turn within these fields, turning towards Lefebvre and explicitly addressing the spatial in order to illuminate community transitions.

For Lefebvre, space is not a container or category, but is itself a product. Drawing on Marxist theories of production, Lefebvre argued that '(Social) space is a (social) product' ([64], p. 26). Space is produced in various ways and always under the guise of whichever mode of production is dominant at that time. The Production of Space begins with discussion of space under Cartesian logic, where space is assumed to be objective (res extensa), not subjective (res cogitans). Very quickly though Lefebvre makes it clear that the key problematic thinker of space to be overcome is not Descartes, Newton, da Vinci, or even Plato, but Kant. 'Kantian space ... was quite clearly separated (along with time) from the empirical sphere' ([64], p. 2). Lefebvre grounds space, and its production in empirical reality, away from any a priori assumption as to what space is or is taken to be. Space for Lefebvre then, is not thought of as Cartesian extension-space as spatium: co-ordinates; length, depth and breadth; lines, dots, and patches; Euclidean geometry; a container. At heart, Cartesian space for Lefebvre is an abstraction. Yet, Lefebvre's great contribution was not to redress the balance from abstract space, towards 'real' empirical space-space as we see and find it-but to problematise this binary from the outset, and to insist on an irreducible third aspect to space: lived space.

Lefebvre proposed a dialectical way to understand space. That Lefebvre characterized three distinct modes of space caused Soja to call this a 'trilectic' (1996, p. 8). First, there is an obvious way of seeing space as physical and material-buildings, car parking spaces, trees and streets. This he called 'spatial practice' ([64], p. 38) also using the qualifier 'concrete space'. Soja [65] translated this as 'real space'. Secondly there is space as it is conceived-maps, street plans, diagrams, more geometrical and fixed. Lefebvre's term for this was 'representations of space' ([64], p. 38). This second aspect of space has tended to be more dominant in how space has been understood and theorised. Lefebvre linked it to Cartesian and Euclidean space, Soja introduced it to English as 'imagined space', whereas Lefebvre also calls it 'abstract space'. As a Marxist, Lefebvre takes these two ways of thinking of space dialectically. From the thesis of spatial practice/real space, and the antithesis of representations of space/imagined space, emerges the synthesis of les espaces de representation ([66], p. 49). In English this is translated as 'representational spaces', though some prefer 'spaces of representation' and Soja 'real-and-imagined space' (see Table 1).

While notions of space and representation as understood by Henri Lefebvre are canonical within human geography, Lefebvre and the turn to the spatial still matters. For Lefebvre, 'there is a politics of space, because space is political' ([57], p. 183; [67], p. 59). As Brenner and Elden put it:

'It is precisely because patterns of spatial organization continue to have such strategic significance to capital, states, and social forces at all scales that such concerted political strategies are being mobilized to reshape them. The politics of space thus remain as contradictory and contentious as ever, and their consequences for everyday life remain to be fought out in diverse territorial arenas and at a variety of scales'

([68], p. 33)

This article then seeks to contribute to this politics of space then. It looks to the micropolitics at the scale of the street, as a way to see how space, togetherness, community and energy transition are imbricated.

\section{Applying spatial theory to community transitions}

Community transitions have emerged in harmony with a variety of actor's vested interests. State deployment of community to meet low carbon legislation and targets emerge because community is seen as cheaper, more 'effective', and delegates environmental responsibilities away from the state to society at arms length $[14,69,70,28,29]$. For volunteers and activists, atomisation in western society and weakening of formal civil society social institutions-churches, trade unions, neighbourhood associations-can leave community movements as a more attractive means of finding concrete connection and belonging with others [71,52,23,24,72]. This distinction is well established in the literature. That from the so-called 'top-down' community is deployed in an abstract manner and is used to contain citizens and corral subjectivities [73-76]. Often this is contrasted with the so-called 'bottomup' approach through which community is understood as a more phenomenological entity. That is, understood through the real and tangible materiality of specific social arrangements of togetherness [5,77,78,3]. Less often however are these two divergent approaches brought together.

The argument of this paper is that the community of community transitions is both the top-down government-preferred community and the bottom-up grassroots emergent community. This both/and, rather than either/or approach can be understood to follow Lefebvre's 'trilectic' above. Following Lefebvre, the differences in the community lying behind the word or term 'community', results from how they are spatialized. What appears to be a straightforward community project in 'real space' (a street, introduced below) belies key differences. One the one hand there exists community as a network of social relations that is contained within physical and material boundaries-in this case a street. Yet, the community receiving funding to carry out this project required being grasped in a cartographic sense. The funded 'community' was geometrical and fixed, assumed to have certain qualities and capabilities. Yet another, third community, could only be known through engagement, interaction and experience within it.

The argument will be that one reason for misunderstandings between those funding community transitions and those communities receiving funding, relates to how community is spatialized. Abstract, objective, cartographic categories of community fit within Lefebvre's three-fold model as the conception of community. The tangible reality of everyday interactions was different though and can be seen as the community that was perceived by the residents. Yet, under this dialectic neither of these gets to grips with Lefebvre's synthesis, lived space. The lived community here could neither be reduced to the conceived one-the street as a container for the community. Nor though could the

Table 1

The 'trilectic' of space.

\begin{tabular}{|c|c|c|c|}
\hline & Spatial Practices & Representations of Space & Spaces of Representation/Representational Spaces \\
\hline Adjective used by Lefebvre & Concrete space & Abstract space & Meaningful space \\
\hline Qualifier used by Soja & Real space & Imagined space & Real-and-imagined space \\
\hline Soja's three spaces & Firstspace & Secondspace & Thirdspace \\
\hline Verb used by Lefebvre & Perceived space & Conceived space & Lived space \\
\hline
\end{tabular}


intangible community of this project be reduced to the perceived one-the specific people, their tangible actions, material relations and achievements. This 'third community' emerged out of the dialectic between both the abstract, conceived community and the perceived, real community of the street, which, confusingly, also simply went by the name of community. It is this third 'lived community' that will be outlined here.

\section{Methods}

The aim of this paper is not only to show the tensions emerging between differing spatial perspectives, and the community(ies) based on that. Rather, the aim is also to bring differently spatialised communities together, and emphasise the always already-existing connections between how a spatially-perceived community overlaps with a community as lived space. The methods adopted here then must be of the both/and type, and include ways to access both the internal, intersubjective aspects of community living, alongside more standard external and set-apart analysis of the community involved in transition: discourse analysis, semi-structured interviewing, and policy analysis. Each of these well established research techniques were adopted here, but more space need to be given to justify the ways in which community is experienced from within.

More formally, the case study reported here was one part of a wider UK-based ESRC-funded project, led by Harriet Bulkeley (Award Number: RES-066-27-0002) designed to investigate the use of community initiatives in the pursuit of low carbon aims and objectives. As part of the wider project, the particular empirical evidence relied on for this paper includes a focus-group with key stakeholders and 15 semistructured interviews with: street residents, some of those volunteering for the community initiative, each of those paid by the funding raised, and at least one interview at each level of the funding chain (panel members allocating funding, those administrating the scheme, external auditors, political and civil servants responsible for it). An investigation into this policy more directly has already been published [79], for this particular paper though, an 18-month period of ethnographic embedded research played a significant role.

Embedded research on the community aspects of sustainability transitions is not new $[80,81]$. Freytag et al. [82] for example, discuss one of the most prevalent examples used in contemporary urban sustainability transitions, not Transition, but the Vauban 'green neighbourhood' of Freiburg. They argue that their 'private ties' and even living in Vauban and the Solarsiedlung (solar estate) does not compromise their research on it. Rather their close, intimate and embedded role as participants and researchers 'should be considered as a resource rather than a limitation' ([82], p. 650). It is this source of rich, qualitative data that allows them to answer certain questions that a broader, expert or surface analysis might miss the subtlety of. Freytag et al. parody international visitors and experts "who literally drop in to discover the Vauban district and Solarsiedlung neighbourhood during a short stay of a few days or more often just a few hours' [82]. They contrast this with their embeddedness to make a wider point about the nature of methodology in seeking certain epistemological claims. 'Articulating our thoughts and presenting our research cannot be anything else than being embedded in and contributing to the on-going social construction of narratives and geographical imaginations about Freiburg's Solarsiedlung and the green city' ([82], p. 650). Something very similar exists with the Transition movement. They have become not only the darling of funding schemes such as the one addressed here, but also a much researched and academically discussed example. This paper builds on this bulwark of academic attention, but also seeks to offer an insider's perspective to the movement-in this case as an insider to the 'Transform the Street project', discussed below.

This methodological approach is not without its challenges though. Krzywoszynka et al. [91] point out that participative approaches in energy research are much more power-laden than often acknowledged.
Merrifield proposes that a geographer can become 'a person of action, a radical problem-raiser, a responsible critical analyst participating with the oppressed', but crucially warns against the hazards of adopting such a stance: becoming an 'overzealous - though well-meaning - academic geography[er]', 'degenerat[ing] into a paternalism reminiscent of 19th century Western missionaries and settlement houses' ([83], p. 63). Standardised (traditional or sedimented) methodologies have been developed and honed to seek answers to an array of questions. In the field of sustainability transitions these may be questions around assessing planning strategies, policy objectives, or the quantitative, technological or economic aspects of sustainability transitions. However the richer, intensive micro-analysis of the sociological or inter- and intrarelatedness requires a time commitment on behalf of the researcher. Ideally this is done from an embedded perspective. In terms of the article here, claiming that a distinction occurs between community as known from inside or outside and is tied up with one's spatial perceptions, conceptions, or living can only be made from the insight that an insider perspective affords.

So, researcher positionality is key here. This is the point to draw attention to not only the embedded research position, but also to the awarenesses, and rich and fulsome data generated through this experience. Less advantageously though, the data being reported here must always be kept in mind as 'biased', in the sense that it is compromised from an insider's perspective. This includes the researcher's broad alignment and sympathies with the aims and motivations of the group studied here, and the Transition movement more generally.

\section{6. 'Transform the Street'}

Transform the Street $(\mathrm{TtS})^{2}$ is a scheme developed by a local Transition group. TtS focused on a stone-built 19th century inner-city tenement street, aiming to find novel and bespoke ways to reduce energy consumption. Granted $£ 79,500$ of funding by the Scottish Government's Climate Challenge Fund (CCF), TtS commissioned detailed NHER (National Home Energy Rating) surveys of the streets' typical households, and employed various energy transition strategies attempting to enroll the relationships integral to community-initiatives towards strategic aims. Yet these two modes of community-community of place focused on carbon footprints or conversely community as relationships, collective action and belonging-remained distinct. TtS worked in conjunction with partner organisations, environmental education charities and environmental consultants. These provided assistance in training Transition volunteers and gave detailed advice on energy efficiency and micro-renewables.

Transition and TtS have different 'target communities'. The Transition group 'represents' a stretch of urban environment, a population of at least 20,000. In contrast, TtS adopted an intensively narrow focus: a single street of 200-250 residents. Despite feeling they were welcoming and open, the group became frustrated with working across a wider area, and seeing the 'usual suspects' turn up to events and get involved. Therefore narrowing one's focus to a single street became an opportunity for a 'deep rather than a shallow' transition, as one member of staff put it. This project was conceived by the wider Transition initiative as a chance to deeply engage in a focused way on transitioning a street.

$\mathrm{TtS}$ was also designed in order to receive funding from the Scottish Government's Climate Challenge Fund (CCF). Thus, the scheme was conditioned by CCF expectations from the outset. Yet volunteers talked about the seemingly snug fit between their, and the CCF's, aims: 'they were going to pay us to do what we would have done anyway' said one. However, the longer I spent with this Transition initiative and familiarised myself with the funding scheme and its effects, I was unsure if this connection amounted to much more than a shared commitment to

\footnotetext{
${ }^{2}$ Anonymised here.
} 


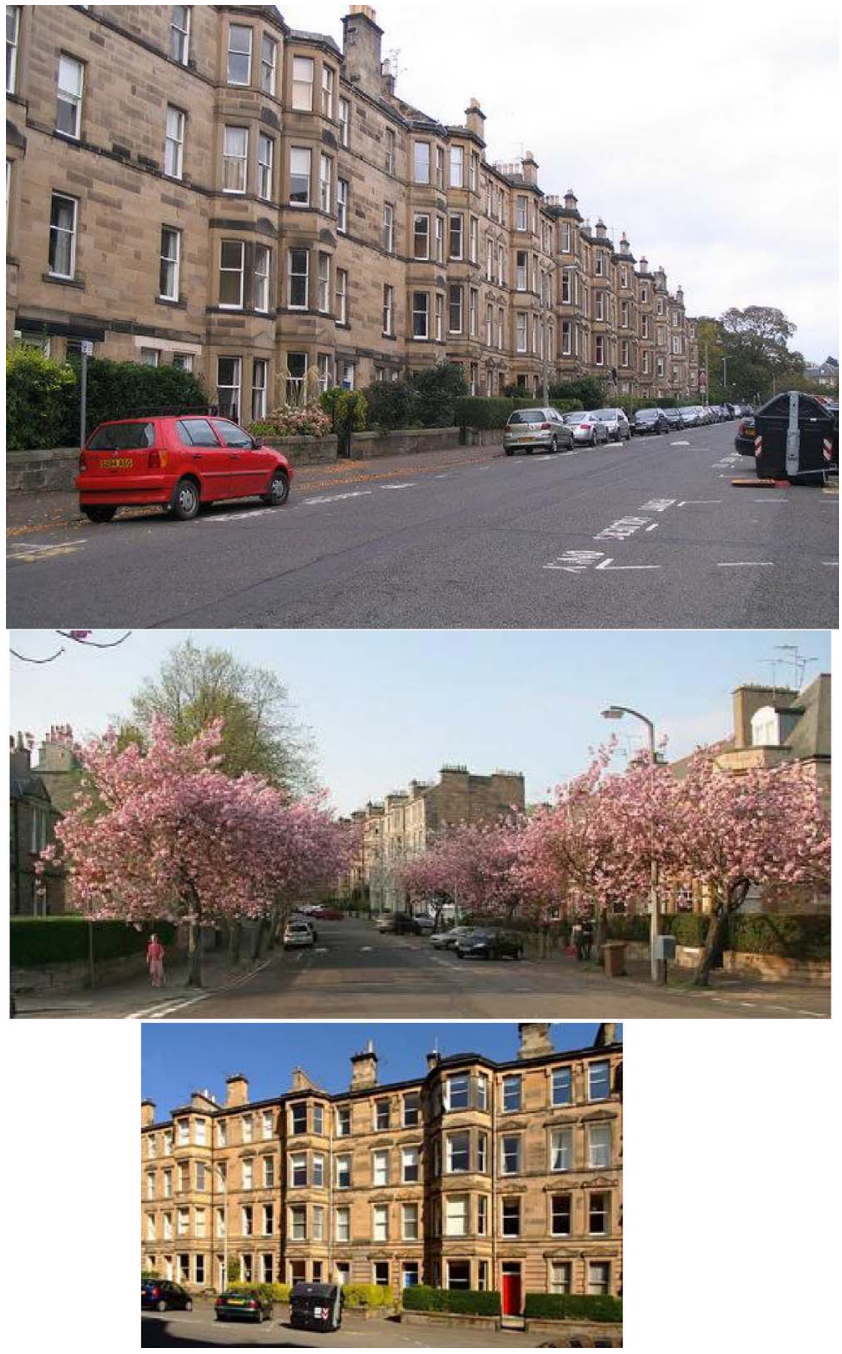

Plate 1. Pictures of the street where Transform the Street took place.

the capacious concept of 'community'. Here, what transitioning a street means is all-important. The location focus makes the intensive micropolitics of community governance readily applicable in a focused way. Territorially defined and bounded by location, it sees a target community as locally defined community of place [79]. The street community is tasked with reducing carbon: a specific number to cut. It is also a vision of community as an area which contains people and subjects and is more readily intelligible by government funders.

\subsection{The street}

The four-storey tenement buildings in the street chosen for TtS have small gardens only for those who live on the ground floor, and shared stairwells for those on floors 1-3. (Plate 1 shows pictures of this street.) With a reputation for being an affluent area, Zoopla ranks the street postcode at the highest possible level in three categories: 'family income', 'interest in current affairs' and being 'educated to degree level'. ${ }^{3}$ In the ACORN designation of UK postcodes, it is in the 'Educated Urbanites' category, 'Number 16: Prosperous Young Professionals - flats'. ${ }^{4}$ The housing in the street is mostly traditional Scottish central-belt tenements. These are well built but lack some basic energy efficiency measures, such as double-glazing. Like much of the city centre it is also

\footnotetext{
3 http://www.zoopla.com Accessed 1 March 2017.

${ }^{4}$ http://acorn.caci.co.uk Accessed 1 March 2017.
}

in a conservation area, meaning there are strong legislative hurdles to certain retrofitting proposals. For example, only recently has the law changed to allow sash windows, required by the conservation bylaws in some flats, to be double-glazed.

Given this, TtS's vision of an energy efficient street community is a challenging one. However, it is also one where much headway can be made given the low environmental performance starting point. TtS's techniques for achieving this 'transition' are their commitment to taking 'a novel, grassroots approach to tackling sustainability at an individual and community level' ([84], p. 6). Their aim has dual foci: 'to build an increasing sense of community, and work towards sustainability' [84]. It is important to identify that for TtS environmental concerns are only half of their raison d'être: as for Transition more widely community is also central. It is both the destination, the intended outcome of their activities, and also tool or technique they will use to achieve their aims. For TtS, community is both means and end.

\subsection{Transform the Street techniques}

The main technique TtS employs is Motivational Interviewing (MI). This involves targeted and repeated interviews with residents about their carbon lives, providing information and encouraging them to take low carbon decisions and actions. TtS's direct engagement with residents can and does have individual impact, and indeed this is encouraged in the training of potential interviewers, which I underwent. When combined with other TtS activities MI is prevented from becoming a 'glorified environmental pep talk', as one critical Transition volunteer called the process. Similar to governmentalised community, particular aspects to MI's approach make the location-based 'community' integral. TtS takes the information from the interviews with householders and then analyses it to create what they call a 'community audit'.

TtS's Community Audit identifies trends and clusters of similar thoughts, motivations, or struggles in householders' attitudes. When combined with data from the energy surveys, focusing on a single street becomes more understandable. Close neighbours can be put in touch with those who are undergoing similar challenges and share thoughts on their environmental impact. Here the community dimension sees close residents supporting and mutually reinforcing certain (visible) behaviour norms. Often however, residents may have had little or no contact with those who they live in close proximity to. The urban setting can limit the impact neighbourly norms have too, for example one clear outward sign of an environmental purchase, or 'virtue signaling' mentioned, the difference between a hybrid vehicle and a $4 \times 4$, would not play out in this urban terraced street with its dearth of parking spaces. Even through the sharing of stairwells and floors, ceilings and walls, tenement living can be just as individualistic as the wider UK society. ${ }^{5}$ The subtle reinforcing of behavioural norms that community produces can have less impact in an urban setting than theorised, or wished, by TtS.

With grander ambitions, the NHER report identified the potential for certain micro-generation opportunities. Where there is a cluster of residents who are interested in certain options, TtS brings them together with suppliers and can offer reduced prices, economies of scale, for such measures. This is perhaps the innovative area with the greatest potential in their plans. The costs and benefits are spread across the street residents buying into the scheme.

The built infrastructure in this street means any action on energy efficiency impacts on neighbours. Due to household centred energy bills there can be little incentive for households to 'team up'. For example, were a flat on the 2nd floor to seal some of the cornicing, and reduce

\footnotetext{
${ }^{5}$ One resident told me that in over 20 years of living in their family home, (s)he had only once came into contact with the family above - and that was when their shower broke and leaked into their flat below.
} 
the cold-bridging-which the reports identified as a major loss of heat in the flats. The loss of heat to the flat above, the 3rd floor in this instance, then has to invest more in energy. The savings on the second floor might be offset by the third. Residents mentioned this possibility frequently. Some of the residents were quite up-front about their own individual flat focus; not seeing the problems on a 'street view' as TtS might wish or idealise. There are options like heat loss through windows-outside-where this is not the case too.

The economies of scale, the infrastructure, and the forming of clusters of similarly inclined groups within the street are all factors that rely on the locational proximity of the residents. A 'Waldo Tobler' vision of community. ${ }^{6}$ Beyond this, the community was seen as having sufficient depth and social agency to enable 'getting things done'. The fusing of reified location and practical action is in the overlap between community as location and activity. Again community's heritage is of continued polysemy, and the multiple, at times contradictory, invested meanings.

In the evaluation of the funding scheme (the CCF) the specific achievements of TtS were listed as:

- Around 40 people trained in motivational interviewing and home energy advice

- Home visits and motivational interviewing achieved with 70 households in one target area

- 2 referrals to installers, 8 participants pledged to install loft insulation, and 4 pledged to get double glazing

\section{([88]: 20)}

TtS was deemed to succeed in making an impact in three of the CCF's four foci: 'energy consumption', 'insulation', and 'other energy efficiency measures', but not 'domestic renewable energy' ([88]: 23). Crucially for this project, and the ways allocation of funds were evaluated, is the carbon 'saved'. TtS had a 'total lifetime saving' of between 348 and $464 \mathrm{CO}_{2}$ e, equivalent to 53-71 average households annual domestic energy use ([88]: 37). Within the review of the funding scheme in general specific aspects of TtS were single-out for praise. This included the ways 'intermediaries [i.e. non-state actors] engage local residents in energy efficiency through motivational interviewing' ([88]: 12). For the funding scheme Motivation Interviewing was a key reason of both why TtS received funding, and that this funding was deemed successful. CCF panel members praised the focus on residents (as a community) as getting beyond the 'usual suspects' of 'those who do the rounds'-i.e. those who are socio-demographically predisposed to optinto voluntary initiatives such as Transition. In Lefebvre's terms, it appears that the CCF preferred a conceived community to a lived one.

\subsection{Spatialising community transitions}

While the central focus here is Lefebvre, there are many overlaps with the concept of 'communities of practice' [92]. Communities of practice was one of many new definitions of community which pushed beyond territorial definitions like community of place. Members of a community of practice may well be co-located in a physical setting like a street, but they are not at all bound by that. What solidifies and gels this community on the other hand is 'mutual engagement, a joint enterprise, and a shared repertoire of ways of doing things' ([85], pp. 49, 73). Communities of practice are not on the opposite pole to community of place: what is regularly set against place as 'community of interest'. What binds social togetherness in a community of practice is not an identity definer-whether chosen or pre-given, intentional or unintentional-but the practices undergone, what people actually do, together. "A residential neighbourhood is often called a "the community"

\footnotetext{
${ }^{6}$ Tobler's 'first law of geography' states: Everything is related to everything else, but near things are more related than distant things.
}

but it is not a community of practice. Playing scales on the piano is often called practice' but is not what Wenger calls a community ([85], p. 72). Rather it is the involvement in what, in a related but separate context, Schatzki [86] calls activity space, or activity timespace.

In sum, there were some aspects of community that could be put to use in attempting to target and reduce the carbon footprint of each household in this scheme. Economies of scale and the focus on territorial location and residence could all be objectively utilised and understood. We can identify these as a form of social relations spatialised as community of place, fitting with Lefebvre's 'abstract space'. The street here is a container for one's social relations, and interpersonal interactions. The implications of this can be profound. That only part of what a community is (or could be) is deployed governmentally. Where policy aims at harnessing community to pursue low carbon objectives, that they are objectives means that only one form of spatialised community (objective, conceived community) is referred to or grasped. Castán Broto et al. ([87], p. 193) showed that multiple energy relationships exist alongside multiple communities as organizational structures, groups of houses, or 'social and material exchanges across a wider neighbourhood'. In this case, the territorially defined, community contained within the street, was only one of many possible communities.

In our schema here, a community based in or on place loosely fits with community in 'real space'. A group of people connected by and through their relationships to the street: obviously residents, but also regular visitors to residents, people often passing through from the postie, to dog walkers on their regular route. Separately, a group (a community for some) with the same postcode and street address were residents. This community was solely defined by location, and perhaps administratively too (for instance were they registered on the electoral role, or allocated to this street by the council). This is community in abstract space and an extreme, or straw man, community of place-it exists territorially or administratively, but not socially or intersubjectively. Third we have community based in meaningful or lived space. These social relations can be seen as a community of practice-a shared 'mutual engagement, joint enterprise and ways of doing things'.

However I do not want to artificially tear apart too far these three forms of community loosely based on the street. Lefebvre is a helpful explanatory framework here because space can be concurrently conceived, perceived and lived. Likewise in this case, the community(ies) based on these spatial awarenesses are concurrent and interrelated. Parsing them serves as an analytical purpose, but some individuals were resident and a part of the social fabric of both the street and the $\mathrm{TtS}$ project. Some were only in one or two of these categories, and the boundaries between them are far more loosely held and flexiform than clearly demarcated.

Here, there were other aspects of community that could not be so easily put to use. There remained-despite the intention of the volunteers, the quantity of funding, and the effort designing and implementing the TtS scheme-two separate groups. These two communities (for want of a better word) were first the target community of the street, those whom the project and transition was done to. Separately there existed those doing the transition: the active Transition group, those volunteering, carrying out the interviews, and committing time, energy, and talents for the Transition projects and activities. This was a community with solid social bonds and a reasonably cohesive entity that did not map onto the street; some were residents, some were not. Some travelled as far as 20 miles to participate in this group and project. Such a community is sustained by feelings of belonging to a collective of likeminds or by the feeling of doing something useful. Despite the internal differences within this community initiative, they could all be seen as a concrete and real entity. There was a passive, conceived community of the street, and an active lived one. An object-community of street (res extensa) and a subject-community of action (res cogitans). It was those in the second group that had feelings of active involvement, of belonging to something greater than themselves. These were the ones 
Table 2

The 'trilectic' of space, including how community is spatialised in this case.

\begin{tabular}{|c|c|c|c|}
\hline & Spatial Practices & Representations of Space & Spaces of Representation/Representational Spaces \\
\hline Adjective used by Lefebvre & Concrete space & Abstract space & Meaningful space \\
\hline Qualifier used by Soja & Real space & Imagined space & Real-and-imagined space \\
\hline Soja's three spaces & Firstspace & Secondspace & Thirdspace \\
\hline Verb used by Lefebvre & Perceived space & Conceived space & Lived space \\
\hline $\begin{array}{l}\text { Three types of community in } \\
\text { TtS }\end{array}$ & $\begin{array}{l}\text { Friendships, social ties, activities, only loosely } \\
\text { related to the street. Intentional and } \\
\text { unintentional. }\end{array}$ & $\begin{array}{l}\text { Residents comprise the community. } \\
\text { Unintentional community }\end{array}$ & $\begin{array}{l}\text { Residents and those Transition volunteers } \\
\text { committed to the project. Intentional and active. }\end{array}$ \\
\hline Relationship to funding & $\begin{array}{l}\text { Only tangentially related to the funded project. } \\
\text { Exists as a 'folk' understanding in these interviews }\end{array}$ & $\begin{array}{l}\text { Funding was directed towards this } \\
\text { community }\end{array}$ & This community won and arranged the funding \\
\hline $\begin{array}{l}\text { What does transitioning the } \\
\text { street mean? }\end{array}$ & $\begin{array}{l}\text { Not a relevant question to those solely in this } \\
\text { community }\end{array}$ & This community is to be transitioned & This community does the transitioning \\
\hline
\end{tabular}

who had an appreciation of what this paper terms 'lived community'.

The street's residents can be seen as comprising the 'conceived community', those contained within the boundary of the street, having a place of residence and street address. There was also-loosely associated with this-a 'real' or concrete' community. These are the spatial practices that socially tied residents into a community of place. At times these were completely absent, where residents has little or no relationship or engagement with those nearby. However, what this project intended was, through the TtS project, to deploy these everyday encounters and real connections with people in order to produce a vibrant low carbon community of the street. This Thirdspace, or lived space, certainly occurred, though not as intended. There was a vibrant and active small section of street residents who volunteered, engaged with the interviewing process and also belonged to the street as a resident. However, they were a minority. Most residents kept their existing social ties and felt no need to fuse the two (Table 2).

\section{Conclusion}

Community can connote a practical belonging to those it includes [90]. Yet community is excessive to this definition, something captured by the term lived community, its inherently assumed practical action. Transition assumes that those in any community are not merely contained by it, but involved within it. This meaning is not strictly either connoted or denoted by Transition. It is implied in that the community is itself a movement. Assumed innate to community, it is in the doing that community is understood, in practice not definition. This doing is not understood in a rational, codified sense. Rather it 'just is'. Appropriately, the best definition of this understanding of community came not from academic theory or literature, but by one interviewee (Transition volunteer) who said community was not a noun to be defined, but a verb; an action not understood conceptually, but realised in the doing. The bridging word community, a quilting point, has allowed Transition to become the darling of UK funding schemes such as the Scottish Government's Climate Challenge Fund, or England and Wales' Low Carbon Community Challenge. Yet, this capacious community, by attempting to hold so much within the one word, can also cause tensions.

This article outlined one government-funded community project to lower the energy consumption of an urban street. Here, a grassroots desire to 'do something' about environmental challenges harmonised with state-supported reconfiguring of energy-related behaviours. The resulting intervention is increasingly relevant: not only because similar examples of state and community actors collaboratively intervening in energy relations abound; but also because of what these specific dynamics have to say about community's spatiality. This scheme not only focused on the physical infrastructure of the street (retrofitting, installing renewables) but also the lived experience and residents' patterns of behaviour.

By invoking canonical geographical theories of space, the paper outlines the different communities at play. One community is territorially delimited, location-bound, and static: the street, and its residents.
Another community is networked, performative, and interpersonal: those involved in the community project. These forms of community correspond, respectively, to space as both a container-the community being transitioned-and as a co-constructed social space-the community doing the transitioning. This article again finds that community is polysemic, and also pushes further in order to tease out how community is understood, approached, and acted out (Lefebvre would say perceived, conceived and lived) is inherently tied up with its spatiality. In reflecting on the spatial implications different forms of community produce (and are in turn produced by), the article argues, alongside the rest of the special edition, for a greater appreciation of the imbrication of space, community and energy as mutually co-constitutive.

\section{References}

[1] L. Middlemiss, B.D. Parrish, Building capacity for low-carbon communities: the role of grassroots initiatives, Energy Policy 38 (2010) 7559-7566, http://dx.doi.org/10. 1016/j.enpol.2009.07.003.

[2] G. Feola, R. Nunes, Success and failure of grassroots innovations for addressing climate change: the case of the Transition Movement, Glob. Environ. Change 24 (2014) 232-250, http://dx.doi.org/10.1016/j.gloenvcha.2013.11.011.

[3] G. Seyfang, A. Haxeltine, Growing grassroots innovations: exploring the role of community-based initiatives in governing sustainable energy transitions, Environ. Plan. C Gov. Policy 30 (2012) 381-400, http://dx.doi.org/10.1068/c10222.

[4] G. Seyfang, A. Smith, Grassroots innovations for sustainable development: towards a new research and policy agenda, Environ. Polit. 16 (2007) 584-603, http://dx. doi.org/10.1080/09644010701419121.

[5] P. Chatterton, Building transitions to post-capitalist urban commons, Trans. Inst. Br. Geogr. 41 (2016) 403-415, http://dx.doi.org/10.1111/tran.12139.

[6] H. Bulkeley, Accomplishing Climate Governance, Cambridge University Press, Cambridge, 2015.

[7] J. Murphy, A. Smith, Understanding transition periphery dynamics: renewable energy in the Highlands and Islands of Scotland, Environ. Plan. A 45 (2013) 691-709, http://dx.doi.org/10.1068/a45190.

[8] M. Markantoni, M. Aitken, Getting low-carbon governance right: learning from actors involved in Community Benefits, Local Environ. 21 (2016) 969-990, http:// dx.doi.org/10.1080/13549839.2015.1058769.

[9] B.J.A. Walker, B. Wiersma, E. Bailey, Community benefits, framing and the social acceptance of offshore wind farms: an experimental study in England, Energy Res. Soc. Sci. 3 (2014) 46-54, http://dx.doi.org/10.1016/j.erss.2014.07.003.

[10] E. Creamer, The double-edged sword of grant funding: a study of community-led climate change initiatives in remote rural Scotland, Local Environ. 20 (2015) 981-999, http://dx.doi.org/10.1080/13549839.2014.885937.

[11] E. Creamer, "Community": the Means and Ends of Sustainability? Exploring the Position and Influence of Community-led Initiatives in Encouraging More Sustainable Lifestyles in Remote Rural Scotland (PhD), University of Edinburgh, Edinburgh, 2015.

[12] M. Markantoni, Low carbon governance: mobilizing community energy through top-down support?: Low carbon governance, Environ. Policy Gov. 26 (2016) 155-169, http://dx.doi.org/10.1002/eet.1722.

[13] G. Taylor Aiken, L. Middlemiss, S. Sallu, R. Hauxwell-Baldwin, Researching climate change and community in neoliberal contexts: an emerging critical approach, Wiley Interdiscip. Rev. Clim. (2017) e463, http://dx.doi.org/10.1002/wcc.463 Change 8.

[14] W. Eadson, State enrolment and energy-carbon transitions: syndromic experimentation and atomisation in England, Environ. Plan. C Gov. Policy (2016), http:// dx.doi.org/10.1177/0263774X16629445.

[15] J. Stripple, H. Bulkeley, Governmentality, in: K. Bäckstrand, E. Lövbrand (Eds.), Research Handbook on Climate Governance, Edward Elgar Publishing Cheltenham, UK, Northampton, MA, USA, 2015, p. 5.

[16] J. Stripple, H. Bulkeley (Eds.), Governing the Climate: New Approaches to Rationality, Power and Politics, Cambridge Univ. Press, New York, NY, 2014.

[17] B. van Veelen, C. Haggett, Uncommon ground: the role of different place 
attachments in explaining community renewable energy projects, Sociol. Rural (2016), http://dx.doi.org/10.1111/soru.12128.

[18] H. Bulkeley, S. Fuller, Low Carbon Communities and Social Justice, (2012).

[19] W. Eadson, M. Foden, Editorial: critical perspectives on community energy, People Place Policy 8 (2014) 145-148, http://dx.doi.org/10.3351/ppp.0008.0003.0001 Online.

[20] A. Forman, Energy justice at the end of the wire: enacting community energy and equity in Wales, Energy Policy (2017), http://dx.doi.org/10.1016/j.enpol.2017.05. 006.

[21] S. Fuller, H. Bulkeley, Energy justice and the low carbon transition: assessing low carbon community programmes in the UK, Energy Justice in a Changing Climate Zed Books, Zed Books, 2013, pp. 61-78 London.

[22] S. Haf, K. Parkhill, The Muillean Gaoithe and the Melin Wynt: cultural sustainability and community owned wind energy schemes in Gaelic and Welsh speaking communities in the United Kingdom, Energy Res. Soc. Sci. 29 (2017) 103-112, http:// dx.doi.org/10.1016/j.erss.2017.05.017.

[23] K. Hobson, J. Hamilton, R. Mayne, Monitoring and evaluation in UK low-carbon community groups: benefits, barriers and the politics of the local, Local Environ. 21 (2016) 124-136, http://dx.doi.org/10.1080/13549839.2014.928814.

[24] K. Hobson, R. Mayne, J. Hamilton, Monitoring and evaluating eco-localisation: lessons from UK low carbon community groups, Environ. Plan. A 48 (2016), http:// dx.doi.org/10.1177/0308518X16640531.

[25] G. Walker, P. Devine-Wright, S. Hunter, H. High, B. Evans, Trust and community: exploring the meanings, contexts and dynamics of community renewable energy, Energy Policy 38 (2010) 2655-2663, http://dx.doi.org/10.1016/j.enpol.2009.05. 055.

[26] S. Fuller, Embedding energy transitions in the community, in: S. Bouzarovski, M.J. Pasqualetti, V.C. Broto (Eds.), The Routledge Research Companion to Energy Geographies, Routledge Abingdon, Oxon, New York, NY, 2017, pp. 265-276.

[27] H. Lovell, The multiple communities of low-carbon transition: an assessment of communities involved in forest carbon measurement, Local Environ. (2014) 1-20, http://dx.doi.org/10.1080/13549839.2014.905515.

[28] G. Taylor Aiken, Polysemic, polyvalent and phatic: a rough evolution of community with reference to low carbon transitions, People Place Policy 10 (2016) 126-145, http://dx.doi.org/10.3351/ppp.0010.0002.0002 Online.

[29] G. Taylor Aiken, Prosaic state governance of community low carbon transitions, Polit. Geogr. 55 (2016) 20-29, http://dx.doi.org/10.1016/j.polgeo.2016.04.002.

[30] G. Walker, P. Devine-Wright, Community renewable energy: what should it mean, Energy Policy 36 (2008) 497-500, http://dx.doi.org/10.1016/j.enpol.2007.10.019.

[31] A. Karvonen, Low-carbon devices and desires in community housing retrofit, in: H. Bulkeley, M. Paterson, J. Stripple (Eds.), Towards a Cultural Politics of Climate Change: Devices, Desires, and Dissent, Cambridge University Press, Cambridge, 2016, pp. 51-65.

[32] A. Fischer, K. Holstead, C.Y. Hendrickson, O. Virkkula, A. Prampolini, Communityled initiatives? Everyday politics for sustainability? Conflicting rationalities and aspirations for change? Environ. Plan. A (2017), http://dx.doi.org/10.1177/ 0308518 X17713994 $0308518 \times 1771399$.

[33] R. Hopkins, The Transition Companion: Making Your Community More Resilient in Uncertain Times, Transition Books, Totnes, 2011.

[34] R. Hopkins, The Transition Handbook: From Oil Dependency to Local Resilience, Green Books, Totnes, Devon, 2008.

[35] B. Brangwyn, What is a transition initiative? Transit. Netw. (2010) https://www. transitionnetwork.org/support/what-transition-initiative (Accessed 1st March 2017).

[36] N. Longhurst, Chapter 9 the totnes pound: a grassroots technological niche, in: A. Davies (Ed.), Advances in Ecopolitics, Emerald Group Publishing Limited, 2012, pp. $163-188$.

[37] M. Scott-Cato, J. Hillier, How could we study climate-related social innovation? Applying Deleuzean philosophy to Transition Towns, Environ. Polit. 19 (2010) 869-887, http://dx.doi.org/10.1080/09644016.2010.518677.

[38] G. Taylor Aiken, Permaculture and the social design of nature, Geogr. Ann. Ser. B Hum. Geogr. (2017) 99, http://dx.doi.org/10.1080/04353684.2017.1315906.

[39] K. Mason, M. Whitehead, Transition urbanism and the contested politics of ethical place making, Antipode 44 (2012) 493-516, http://dx.doi.org/10.1111/j.1467 8330.2010.00868.x.

[40] P. Chatterton, A. Cutler, The Rocky Road to a Real Transition: The Transition Towns Movement and What It Means for Social Change, Trapese Collective, 2008.

[41] A. Kenis, E. Mathijs, (De)politicising the local: the case of the Transition Towns movement in Flanders (Belgium), J. Rural Stud. 34 (2014) 172-183, http://dx.doi. org/10.1016/j.jrurstud.2014.01.013.

[42] G.A. Wilson, Community Resilience and Environmental Transitions, Routledge Abingdon, Oxon, New York, 2012.

[43] J. Kendrick, This hugely hopeful moment, Scott. Left Rev. (68) (2011).

[44] J. Painter, The politics of the neighbour, Environ. Plan. Soc. Space 30 (2012) 515-533, http://dx.doi.org/10.1068/d21110.

[45] E.F. Schumacher, B. McKibben, Small Is Beautiful: Economics as If People Mattered, Harper Perennial, New York, NY, 2014.

[46] D. Holmgren, Permaculture: Principles \& Pathways Beyond Sustainability, Holmgren Design Services, Hepburn, Vic, 2002.

[47] B.H. Walker, D. Salt, Resilience Thinking: Sustaining Ecosystems and People in a Changing World, Island Press, Washington, DC, 2006.

[48] J.D. Graugaard, A tool for building community resilience? A case study of the Lewes Pound, Local Environ. 17 (2012) 243-260, http://dx.doi.org/10.1080/13549839. 2012.660908.

[49] I. Bailey, R. Hopkins, G. Wilson, Some things old, some things new: the spatial representations and politics of change of the peak oil relocalisation movement,
Geoforum 41 (2010) 595-605, http://dx.doi.org/10.1016/j.geoforum.2009.08 007.

[50] A.H. Maslow, A theory of human motivation, Psychol. Rev. 50 (1943) 370-396, http://dx.doi.org/10.1037/h0054346.

[51] M.A. Max-Neef, Human Scale Development: Conception, Application and Further Reflections, Apex Press, New York, 1991.

[52] Z. Bauman, Community: seeking safety in an insecure world, Reprinted, Themes for the 21 st Century, Polity Press Cambridge, 2004.

[53] G. Delanty, Community, Key Ideas, 2nd ed., Routledge, London; New York, 2010.

[54] G. Walker, The role for community in carbon governance, Wiley Interdiscip. Rev. Clim. Change 2 (2011) 777-782, http://dx.doi.org/10.1002/wcc.137.

[55] D.B. Massey, For Space, SAGE, London, Thousand Oaks, Calif, 2005.

[56] S. Elden, Space I, International Encyclopedia of Human Geography, Elsevier, 2009, pp. 262-267.

[57] S. Elden, Understanding Henri Lefebvre: Theory and the Possible, Continuum Studies in Philosophy, Continuum, London, New York, 2004.

[58] S. Bouzarovski, M.J. Pasqualetti, V.C. Broto (Eds.), The Routledge Research Companion to Energy Geographies, Routledge Abingdon, Oxon, New York, NY, 2017.

[59] E. Bomberg, N. McEwen, Mobilizing community energy, Energy Policy 51 (2012) 435-444, http://dx.doi.org/10.1016/j.enpol.2012.08.045.

[60] Y. Mulugetta, T. Jackson, D. van der Horst, Carbon reduction at community scale, Energy Policy 38 (2010) 7541-7545, http://dx.doi.org/10.1016/j.enpol.2010.05. 050.

[61] K. Calvert, From energy geography to energy geographies: perspectives on a fertile academic borderland, Prog. Hum. Geogr. 40 (2016) 105-125, http://dx.doi.org/10. $1177 / 0309132514566343$.

[62] K. Calvert, K. Birch, W. Mabee, New perspectives on an ancient energy resource, in: S. Bouzarovski, M.J. Pasqualetti, V.C. Broto (Eds.), The Routledge Research Companion to Energy Geographies, Routledge Abingdon, Oxon, New York, NY, 2017, pp. 47-60.

[63] M. Huber, Theorizing energy geographies: theorizing energy geographies, Geogr. Compass 9 (2015) 327-338, http://dx.doi.org/10.1111/gec3.12214.

[64] H. Lefebvre, Nachdr (Ed.), The Production of Space, Blackwell Malden, Mass, 2011

[65] E.W. Soja, Thirdspace: Journeys to Los Angeles and Other Real-and-imagined Places, Blackwell Cambridge, Mass, 1996.

[66] H. Lefebvre, La production de l'espace, 4. éd., Ethnosociologie. Éd. Anthropos, Paris, 2000.

[67] H. Lefebvre, Espace et politique, Le droit à la ville, 2. éd., Anthropos, Paris, 2000.

[68] H. Lefebvre, N. Brenner, S. Elden, State, Space, World: Selected Essays, University of Minnesota Press, Minneapolis, 2009.

[69] M. Paterson, J. Stripple, My Space: governing individuals' carbon emissions, Environ. Plan. Soc. Space 28 (2010) 341-362, http://dx.doi.org/10.1068/d4109.

[70] J.L. Rice, The everyday choices we make matter: urban climate politics and the postpolitics of responsibility and action, Towards a Cultural Politics of Climate Change: Devices, Desires, and Dissent, Cambridge University Press, Cambridge, 2016, pp. 110-126.

[71] S. Barr, J. Pollard, Geographies of Transition: narrating environmental activism in an age of climate change and 'Peak Oil, Environ. Plan. A 49 (2016) 47-64, http:// dx.doi.org/10.1177/0308518X16663205.

[72] L. Middlemiss, Individualised or participatory? Exploring late-modern identity and sustainable development, Environ. Polit. 23 (2014) 929-946, http://dx.doi.org/10 1080/09644016.2014.943010.

[73] R. Dowling, Geographies of identity: climate change, governmentality and activism, Prog. Hum. Geogr. 34 (2010) 488-495, http://dx.doi.org/10.1177/ 0309132509348427.

[74] R. Hauxwell-Baldwin, Tackling Climate Change Through Community: The Politics and Practice of the Low Carbon Communities Challenge (PhD), University of East Anglia, 2013.

[75] K. McKinnon, Postdevelopment, professionalism, and the politics of participation, Ann. Assoc. Am. Geogr. 97 (2007) 772-785, http://dx.doi.org/10.1111/j.14678306.2007.00582.x.

[76] J.L. Rice, Climate, carbon, and territory: greenhouse gas mitigation in Seattle, Washington, Ann. Assoc. Am. Geogr. 100 (2010) 929-937, http://dx.doi.org/10. 1080/00045608.2010.502434.

[77] R.M. Cretney, A.C. Thomas, S. Bond, Maintaining grassroots activism: transition towns in aotearoa New Zealand: maintaining grassroots activism, New Zealand Geogr. 72 (2016) 81-91, http://dx.doi.org/10.1111/nzg.12114.

[78] P. North, N. Longhurst, Grassroots localisation? The scalar potential of and limits of the transition approach to climate change and resource constraint, Urban Stud. 50 (2013) 1423-1438, http://dx.doi.org/10.1177/0042098013480966.

[79] G. Taylor Aiken, Common sense community? The climate challenge fund's official and tacit community construction, Scott. Geogr. J. 130 (2014) 207-221, http://dx doi.org/10.1080/14702541.2014.921322.

[80] J.M. Wittmayer, N. Schäpke, F. van Steenbergen, I. Omann, Making sense of sustainability transitions locally: how action research contributes to addressing societal challenges, Crit. Policy Stud. 8 (2014) 465-485, http://dx.doi.org/10.1080/ 19460171.2014.957336.

[81] J.M. Wittmayer, N. Schäpke, Action, research and participation: roles of researchers in sustainability transitions, Sustain. Sci. 9 (2014) 483-496, http://dx.doi.org/10. 1007/s11625-014-0258-4.

[82] T. Freytag, S. Gössling, S. Mössner, Living the green city: Freiburg's Solarsiedlung between narratives and practices of sustainable urban development, Local Environ. 19 (2014) 644-659, http://dx.doi.org/10.1080/13549839.2013.868872.

[83] A. Merrifield, Situated knowledge through exploration: reflections on bunge's geographical expeditions, Antipode 27 (1995) 49-70, http://dx.doi.org/10.1111/j. 
1467-8330.1995. tb00261.x.

[84] 'Transform the Street' manual, Transform the Street Manual, (2010).

[85] E. Wenger, Communities of practice: learning, meaning, and identity, Learning in Doing: Social, Cognitive, and Computational Perspectives, 16th ed., Cambridge Univ. Press, Cambridge, 2008.

[86] T.R. Schatzki, The Timespace of Human Activity: on Performance, Society, and History as Indeterminate Teleological Events, 1. ed., Toposophia. Lexington Books, Lanham, 2013 (paperback).

[87] V. Castán Broto, D. Salazar, K. Adams, Communities and urban energy landscapes in Maputo, Mozambique, People Place Policy 8 (2014) 192-207, http://dx.doi.org/10. 3351/ppp.0008.0003.0005 Online.

[88] Scottish Government, Review of The Climate Challenge Fund, Scottish Government
Social Research, 2011, pp. 1-116.

[89] Transition Network, 2012. https://transitionnetwork. org (Accessed 1 st March 2017).

[90] A.P. Cohen, The symbolic construction of community, Routledge London, 2008 Transferred to digit. pr. ed, Key ideas.

[91] A. Krzywoszynska, A. Buckley, H. Birch, M. Watson, P. Chiles, J. Mawyin, H. Holmes, N. Gregson, Co-producing energy futures: impacts of participatory modelling, Build. Res. Inf. 44 (2016) 804-815, http://dx.doi.org/10.1080/ 09613218.2016.1211838.

[92] J. Lave, E. Wenger, Situated learning: legitimate peripheral participation, Learning in doing, Cambridge University Press, Cambridge [England], New York, 1991. 